\title{
The Growth of International Trade in Services in Developing Countries:Some Implications
}

\author{
Prabir De ${ }^{*}$
}

\begin{abstract}
Services trade has registered a dynamic evolution in almost all developing countries. Despite the rising share in world services trade by developing countries, the gap between developed and developing countries in service exports have been widening. Developed economies have become service exporters, while developing economies are found to be more receptive towards service imports. This paper attempts to gain some insight into the actual nature and extent of exports of services from developing countries, and examines their emergence as significant players of services trade as well as the underlying factors and broader implications. One of the conclusions of this paper is that developing countries successfully export a variety of services to both developed and developing countries, whereas a relatively limited number of developing countries seem to be heavily involved in services exports trade across a range of sectors. This, alternatively, indicates that services exports, on a large international level, are associated with higher levels of development and that not all developing countries are yet in a position to be large-scale exporters.
\end{abstract}

Keywords: Services; Trade Liberalisation; Revealed Comparative Advantage; General Agreement on Trade in Services; Developing Countries.

\section{Introduction}

Trade between developing countries has been growing rapidly in recent years following significant reductions in tariff barriers. Services have become the single largest sector in many developing countries (WTO, 2001, 2004, 2006; UNCTAD, 2004). During the recent past, there has been major structural change in world economy resulting which the service sector has

Submission Date: 10/26/2006 Acceptance Date: 15/12/2006

*Associate fellow, Research and Information System for Developing Countries, Zone 4B, Fourth Fl. India Habitat Center, Lodhi Rd., New Dehli. Tel : +91 112468 2177-80, Fax : +91 11 2468 2173-4 
emerged as the leading sector accounting for $2 / 3$ of world production, $1 / 3$ of global employment and about $1 / 5$ of world trade ${ }^{1}$. The services sector's expansion has been attributed to demand as well as supply factors. On the one hand, demand for many services is highly income elastic, i.e. as people grow richer their consumption of services such as tourism, education and health expands more rapidly than their demand for manufactured and agricultural products. To a certain degree, the growing share of services in GDP also reflects structural changes in an economy. Services sector not only provide the bulk of employment and income in many countries, it also serves as vital input for producing other goods and services. An efficient services sector is not only crucial for the overall economy but also critical to the competitiveness of a country. The importance of services is therefore increasingly reflected in the policy agenda ranging from liberalisation to promotional efforts to regulation at national and international levels (WTO, 2006).

The services sector in most developing countries has emerged as an important and leading sector accounting for more than $50 \%$ of the $\mathrm{GDP}^{3}$. Developing countries have not only achieved a robust growth in trade in services $(23.16 \%$ in 2004) but also surpassed the same recorded by the developed countries $(15.59 \%)^{4}$. The leading role of services in the domestic economy coupled with the recent trends in world trade wherein growth of service trade exceeding merchandise trade point towards the emerging potential of trade in services 5 .

The current success of developing countries in services trade relies more on substantial liberalisation carried on account of the removal of trade and investment barriers and also for the 1997 Asian financial crisis. The underlying economic rationale for these policy reforms is noteworthy. The removal of barriers to trade in services is likely to result in lower prices, improved quality, and higher competitiveness. As with trade in goods, restrictions on trade in services reduce welfare because they create a wedge between domestic and foreign prices, leading to a loss to consumer surplus ${ }^{6}$.

Certain services industries clearly possess growth-generating characteristics. For example, a competitive and well-regulated financial sector leads to the efficient transformation of savings to investment, ensuring that resources are deployed wherever they have the highest returns; and facilitates better risk-sharing in the economy. Countries with fully open telecom and financial

\footnotetext{
${ }^{1}$ Calculated based on World Bank (2006)

${ }^{2} \mathrm{~A}$ good numbers of studies explore why it would be beneficial for developing countries to actively participate in the services negotiation associated with the General Agreement on Trade in Services (GATS). For example, one can refer, Chaudhuri et al., (2004), and Charlton and Stiglitz (2005), on global services trade issues, and Sung (2004), on country specific issues.

${ }^{3}$ In developing countries, services made a major contribution to GDP, with values ranging from 39\% of GDP in Nigeria, to $89 \%$ in Hong Kong, China. Services are also significant for least developed countries (LDCs). In the 49 least developed countries, the average contribution of services exports to GDP was $10 \%$, with some countries reaching peaks of over $50 \%$ (Vanuatu and the Maldives).

${ }^{4}$ Calculated based on UNCTAD (2005)

${ }^{5}$ Refer Gabriele (2004), which provides an excellent illustration of the trends in international trade in services for the last two decades.

${ }^{6}$ Some of the relevant studies are Fink et al. (2002, 2005); Clark et al. (2004)
} 
services sectors grow up to $1.5 \%$ points faster than other countries (Matto et al., 2006) Improved efficiency in telecommunications generates economy-wide benefits, as this service is a vital intermediate input and also crucial to the dissemination and diffusion of knowledge (Luff, 2004). Business services such as accounting and legal services are important in reducing transaction costs (OECD, 2003c).

Foreign Direct Investment (FDI) is a key source of financing for service sector projects such as telecommunications, energy and financial services, etc. in the era of globalisation ${ }^{7}$. New information and communication technologies make it possible to trade in services, making their production increasingly subject to the international division of labour (Luff, 2004). To a certain degree, developed countries are increasingly outsourcing their services to developing countries thereby showing some sort of trade complementarities between the two income groups.

The growth of the share of services in the global economy, greater liberalisation of the sector and resistance to that liberalisation, along with the perception by a number of developing countries that they have few interests in services trade, has led to increased attention to the patterns of trade in services. Services policy reforms are also instrumental in explaining the growth pattern of transitional economies (Eschenbach and Hoekman, 2005). What follows is that the vibrancy in the domestic service sectors in developing countries may be viewed as an indication of the potential for trade in services. The realization of this potential however, will depend on the extent of trade orientation by sectors. This calls for an examination of the trend in trade in different service sectors in developing countries.

In view of the above, this paper attempts to gain some insight into the actual nature and extent of exports of services from developing countries, and examines their emergence as significant players of services trade as well as the underlying factors and broader implications. The organisation of the paper is as follows. Section 2 provides an overview of developing countries position in world trade. Structure of service exports from developing countries is dealt with in Section 3, following which we attempt to measure export competitiveness of developing countries in services trade in Section 4. Finally, conclusions are drawn in Section 5.

\section{Global services trade of developing countries}

Services make up a major portion of the world economy. Measured both in terms of growth and share, global trade in services has risen spectacularly during 1981 to 2004. On average, the rate of growth of global trade in services is found to be higher than rate of growth in goods during the last two decades (Table 1). The same trend continued during 2001 to 2004. In 2004, the estimated total value of world trade in services was about US\$ 4.36 trillion, whereas $1 / 4$ of global trade in services was contributed by the developing countries (Table 2).

${ }^{7}$ See, for example, OECD (2003a, 2003b) 
Table 1

Growth rates of world exports of trade in goods and services ${ }^{\mathrm{a}}$

$(\%)$

\begin{tabular}{|c|c|c|c|c|c|c|c|c|}
\hline \multirow{3}{*}{ Region } & \multicolumn{4}{|c|}{ Trade in Goods } & \multicolumn{4}{|c|}{ Trade in Services } \\
\hline & $\begin{array}{c}1981- \\
1990\end{array}$ & $\begin{array}{l}1991- \\
2000 \\
\end{array}$ & $\begin{array}{l}2001- \\
2004 \\
\end{array}$ & $\begin{array}{l}1991- \\
2004\end{array}$ & $\begin{array}{c}1981- \\
1990 \\
\end{array}$ & $\begin{array}{l}1991- \\
2000\end{array}$ & $\begin{array}{l}2001- \\
2004\end{array}$ & $\begin{array}{l}1991- \\
2004\end{array}$ \\
\hline & \multicolumn{4}{|c|}{ Exports } & \multicolumn{4}{|c|}{ Exports } \\
\hline World & 8.17 & 9.28 & 15.10 & 12.00 & 11.57 & 13.15 & 17.59 & 11.66 \\
\hline Developed economies & 10.32 & 7.28 & 12.75 & 9.35 & 12.68 & 14.43 & 18.12 & 10.18 \\
\hline \multirow[t]{2}{*}{ Developing economies } & 4.71 & 14.49 & 19.07 & 18.45 & 8.51 & 9.97 & 15.44 & 15.97 \\
\hline & \multicolumn{4}{|c|}{ Imports } & \multicolumn{4}{|c|}{ Imports } \\
\hline World & 8.25 & 9.21 & 14.96 & 11.91 & 9.99 & 12.02 & 15.73 & 10.70 \\
\hline Developed economies & 9.90 & 8.18 & 13.18 & 10.19 & 13.78 & 15.15 & 18.90 & 9.80 \\
\hline \multirow[t]{2}{*}{ Developing economies } & 4.88 & 12.38 & 18.26 & 16.34 & 2.39 & 6.19 & 8.48 & 11.80 \\
\hline & \multicolumn{4}{|c|}{ Total Trade } & \multicolumn{4}{|c|}{ Total Trade } \\
\hline World & 8.21 & 9.25 & 15.03 & 11.96 & 10.74 & 12.56 & 16.62 & 11.17 \\
\hline Developed economies & 10.11 & 7.74 & 12.97 & 9.78 & 13.22 & 14.78 & 18.49 & 9.99 \\
\hline Developing economies & 4.79 & 13.43 & 18.68 & 17.39 & 4.63 & 7.62 & 11.07 & 13.57 \\
\hline
\end{tabular}

Note: a)Average annual growth rate.

b) Developing countries are excluding LDCs

Source: Computed from UNCTAD (2005)

Table 2

Trade share

$(\%)$

\begin{tabular}{|c|c|c|c|c|c|c|}
\hline Particulars & 1981 & 1991 & 2001 & 2002 & 2003 & 2004 \\
\hline & \multicolumn{6}{|c|}{ Trade in Goods (Export +Import) } \\
\hline Developed economies & 66.08 & 73.04 & 67.85 & 67.19 & 66.66 & 64.96 \\
\hline \multirow[t]{2}{*}{ Developing economies ${ }^{\mathrm{a}}$} & 33.92 & 26.96 & 32.15 & 32.81 & 33.34 & 35.04 \\
\hline & \multicolumn{6}{|c|}{ Trade in Services (Export + Import) } \\
\hline Developed economies & 70.54 & 78.06 & 73.38 & 73.84 & 74.41 & 73.18 \\
\hline Developing economies $^{\mathrm{a}}$ & 29.46 & 21.94 & 26.62 & 26.16 & 25.59 & 26.82 \\
\hline
\end{tabular}

Note: a)Including LDCs

Source: Calculated based on UNCTAD (2005)

Developing countries have been playing a key role in managing global trade due mainly to its rising share in global trade in both goods and services, particularly during the period 1991 to 2004. This rising share in global trade in goods and services is attributed to the fact that in both trade in goods and services developing countries grew at a much faster rate than that of developed countries during the period 1991 to 2004 (Table 1). However, as opposed to trade in 
goods, the share of developing countries in world trade in services has fallen from $29.46 \%$ in 1981 to $26.82 \%$ in 2004, with an all time low of 21.94\% in 1991 (Table 2). Apparently, global distribution of trade in services is very much lopsided. For example, in spite of having an increasing contribution to world trade in services by developing countries during the period 1991 to 2004 , a considerable portion of $73 \%$ of world trade in services is still managed by the developed countries (Table 2). On one hand, developing countries are net exporters in trade in goods, while, on the other, with a combined deficit of US\$ 55.13 billion in 2004 they are net importers of services trade. At the same time, developed countries with a rising favourable trade balance reaching an all time surplus of US\$ 93.61 billion in 2004, have further strengthened their domination in global trade in services (Table 3).

Table 3

Trade balance

\begin{tabular}{c|c|c|c|c|c|c}
\hline Particulars & 1981 & 1991 & 2001 & 2002 & 2003 & 2004 \\
\hline \hline & \multicolumn{7}{|c}{ Trade in Goods } \\
\hline Developed economies $^{|c|}-90.57$ & -101.06 & -330.49 & -316.32 & -401.44 & -513.97 \\
Developing economies $^{\mathrm{a}}$ & 31.26 & -16.56 & 93.56 & 136.45 & 175.20 & 190.88 \\
\hline & \multicolumn{7}{|c}{ Trade in Services } \\
\hline Developed economies $^{\mathrm{a}}$ & 17.70 & 25.75 & 56.00 & 63.00 & 70.94 & 93.61 \\
Developing economies $^{\mathrm{a}}$ & -64.09 & -56.33 & -39.14 & -44.80 & -46.40 & -55.13 \\
\hline
\end{tabular}

Note: a) Excluding LDCs

Source:Calculated based on UNCTAD (2005)

For developing countries, the contribution of service exports to their total trade is declining. While in 1991, services accounted for 17.08\% of developing countries' total exports, this share has declined to $15.28 \%$ t in 2004 . This also indicates higher growth rates in exports in goods than exports in services in developing countries. Developed countries, on the other, have witnessed higher services exports to their total trade; their share has gone up from $18.35 \%$ in 1981 to $21.23 \%$ in 2004. The gap between developed and developing countries is likely to widen as can be noticed from the falling trend in Fig. $1^{8}$.

\footnotetext{
${ }^{8}$ The 'negative' coefficient of fitted trend line for developing countries in Fig. 1 confirms this.
} 


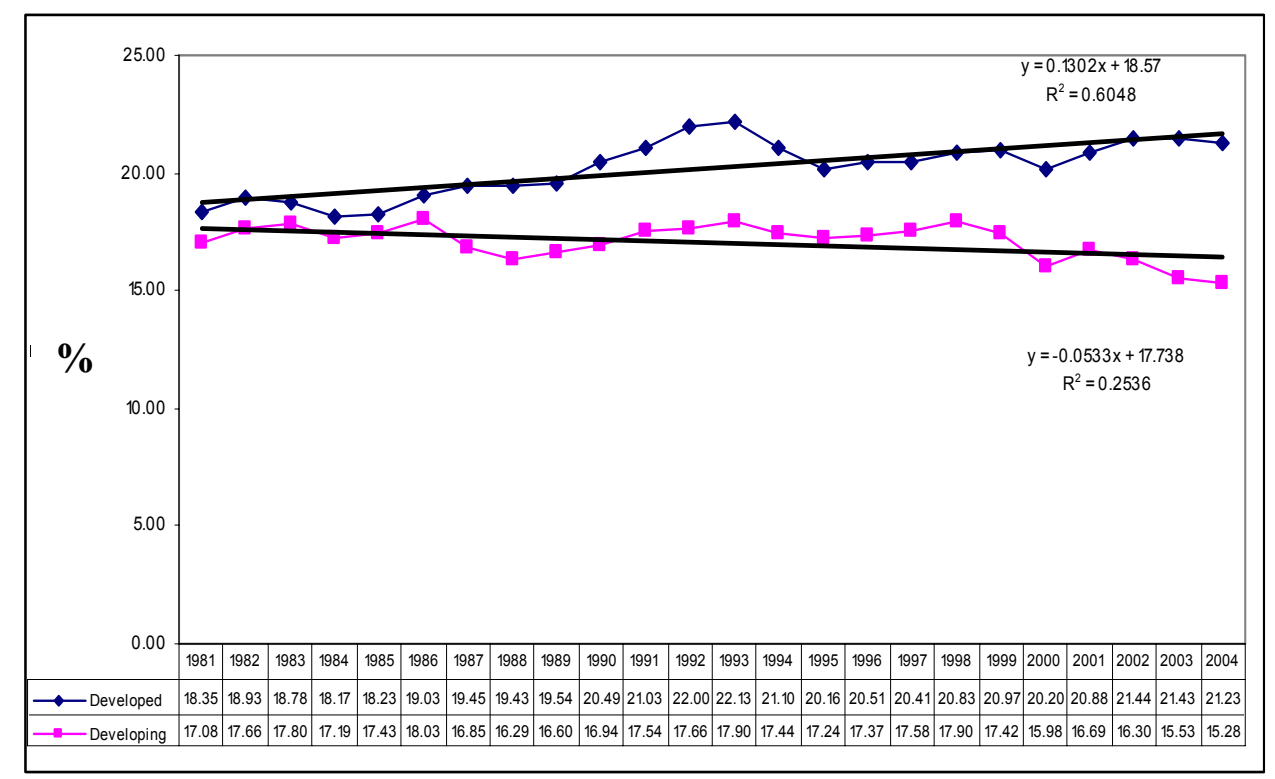

Note: Total trade is composed of trade in goods and services.

Source: Calculated based on UNCTAD (2005)

Fig. 1. Contribution of service exports to total trade

Therefore, what follows is a leading role of the service sector in the domestic economy, and growth of service trade exceeding merchandise trade points toward the emerging potential of trade in services in the world economy. Developed economies have become service exporters, while developing economies are found to be more receptive towards service imports. Indeed, while the majority of world trade in services takes place among developed countries, it is by no means restricted to developed countries. The structural asymmetries in production and trade between developed and developing countries may therefore tend to suggest that the opportunities for twoway services exports among developing countries are substantial.

\section{Structure of services exports from developing countries}

Several components of services, from health, transport, education, tourism, telecommunication, are becoming the single largest sector in many countries. Developed countries dominate global services trade, developing countries are particularly successful in a number of sectors and their performance as exporters of services fits into the broad sectoral pattern of services exports. Using the IMF's Balance of Payment Statistics (IMF, 2006), an attempt has been made to find out the 
sector-wise performance of selected developing countries in services trade ${ }^{9}$. Tables 4 to 10 provide sector-wise trade volume, and sectoral and world shares in exports of services of developing countries for the period 1981 to 2004.

Table 4(a)

Exports of transport Services

\begin{tabular}{l|c|c|c|c}
\hline Country & 1981 & 1991 & 2001 & 2004 \\
\hline \hline Argentina & 0.881 & 1.186 & 0.893 & 1.152 \\
Brazil & 1.087 & 1.457 & 1.422 & 2.467 \\
China, P.R.: Mainland & & 2.011 & 4.635 & 12.068 \\
China,P.R.:Hong Kong & & & 12.012 & 17.358 \\
China, P.R.: Taiwan & & 2.630 & 3.581 & 5.294 \\
Egypt & 1.587 & 2.648 & 2.738 & 4.016 \\
India & 0.456 & 0.975 & 2.050 & \\
Indonesia & 0.068 & 0.081 & & 2.279 \\
Korea & 2.007 & 3.873 & 13.180 & 22.440 \\
Kuwait & 0.800 & 0.503 & 1.203 & 1.751 \\
Malaysia & 0.528 & 1.389 & 2.748 & 3.163 \\
Mexico & 0.477 & 0.901 & 1.282 & 1.362 \\
Philippines & 0.244 & 0.242 & 0.659 & 1.121 \\
Romania & 0.471 & 0.223 & 0.827 & 1.559 \\
Russia & & & 4.654 & 7.792 \\
Singapore & 1.462 & 2.517 & 11.463 & \\
South Africa & 0.594 & 0.642 & 1.163 & 1.417 \\
Thailand & 0.305 & 1.484 & 3.057 & 4.350 \\
Turkey & 0.402 & 1.098 & 2.854 & 3.267 \\
Ukraine & & & 2.961 & 4.041 \\
\hline Sourc: Cal & & & &
\end{tabular}

Source: Calculated based on IMF (2005)

\footnotetext{
${ }^{9}$ More generally, it should be noted that trade in services statistics are likely to under estimate trade in services. Moreover, trade in services between developing countries is more difficult to estimate. To date, the available bilateral data on such trade is scant and does not allow for satisfactory reports on those flows. The discrepancy in the data suggests that services are not only difficult to trade but that, more importantly, under current statistical concepts and methodologies, services trade flows are unlikely to be captured fully. Indeed, many statistics for trade in services are drawn from balance of payments (BOP) data, which has a number of limitations in measuring trade in services from a GATS perspective. Not all service sectors are captured and most figures tend to represent trade via Modes 1 and 2 only - BOP figures do not capture trade via Mode 3 and provide only rough proxies for Mode 4 (OECD, 2005). Mode 3 trade is better captured by Foreign Affiliate Trade in Services (FATS) figures, but these are only collected by a minority of countries (about 20 so far). Proxies for Mode 4 in BOPs - compensation of employees and workers' remittances - are only very approximate and can both under- and over-estimate mode 4 (e.g., they include persons working in sectors beyond services).
} 


\subsection{Transport services}

Exports of Transport services which along with travel services, represent over $50 \%$ of global trade in services (WTO, 2006). Their importance is indirectly reflected in Table 4(b), which show that transport services' share in country's total exports of services is quite high for many of the major developing exporters. For example, Korea, Kuwait and Ukraine, where exports of transport services contribute over $50 \%$ of total exports in services.

Table 4(b)

Share of transport services in country's total services exports

\begin{tabular}{l|c|c|c|c}
\hline Country & 1981 & 1991 & 2001 & 2004 \\
\hline \hline Argentina & 51.34 & 49.25 & 19.30 & 22.06 \\
Brazil & 47.99 & 43.90 & 15.25 & 19.60 \\
China, P.R.: Mainland & - & 28.82 & 13.90 & 19.33 \\
China,P.R.: Hong Kong & - & - & 29.20 & 31.47 \\
China, P.R.: Taiwan & - & 31.04 & 18.00 & 20.54 \\
Egypt & 62.57 & 39.04 & 30.28 & 28.29 \\
India & 16.29 & 19.80 & 11.82 & - \\
Indonesia & 15.14 & 2.87 & - & 12.93 \\
Korea & 65.40 & 38.68 & 45.36 & 54.16 \\
Kuwait & 57.47 & 50.71 & 72.34 & 52.71 \\
Malaysia & 40.15 & 31.76 & 19.01 & 18.86 \\
Mexico & 9.57 & 10.16 & 10.09 & 9.72 \\
Philippines & 13.62 & 6.62 & 20.93 & 27.33 \\
Romania & 42.99 & 32.82 & 40.70 & 43.14 \\
Russia & - & - & 40.68 & 38.40 \\
Singapore & 20.35 & 18.21 & 39.38 & - \\
South Africa & 23.08 & 20.12 & 25.01 & 15.72 \\
Thailand & 18.89 & 20.41 & 23.47 & 22.85 \\
Turkey & 31.78 & 13.12 & 17.77 & 13.59 \\
Ukraine & - & - & 74.12 & 64.28 \\
\hline
\end{tabular}

Source: Calculated based on IMF (2005)

Several developing countries are important exporters of transport services. The largest developing exporter of transport services is Korea, which has experienced a very fast growth in exports of transport services over the period 1981 to 2004. In 2004, Korea's total exports of transport services were over US\$22 billion, contributing over half of country's total exports of services and about $1 \%$ of global service exports. Next comes, China Hong Kong, China Mainland and Singapore. These three countries' transport service exports together contribute over half a percentage of global exports in services (Table 4(c)). Other strong exporters of transport services 
from Asia are Thailand, Taiwan, Malaysia, and India. Among transition economies, Russia, Romania and Ukraine are major players, but their performance over the 1990s has not been progressing, reflecting persistent structural weaknesses in their economies and their difficulties in integrating themselves in global trade. Performance of the largest Latin American countries, namely, Argentina, Brazil and Mexico, in exports of transport services was also not satisfactory during the period 1991 to 2004. What is interesting, exports of transport services in Argentina and Brazil used to contribute about half of the country's total services exports in 1981, which reduced to less than $1 / 4$ of a country's total services exports in 2004. To a great extent, while Asian developing countries have gained in trade in transport services considerably, Latin American countries have witnessed drastic decline in exports of transport services.

Table 4(c)

Share of transport services in world total services exports

\begin{tabular}{l|c|c|c|c}
\hline Country & 1981 & 1991 & 2001 & 2004 \\
\hline \hline Argentina & 0.216 & 0.136 & 0.058 & 0.053 \\
Brazil & 0.267 & 0.167 & 0.093 & 0.112 \\
China, P.R.: Mainland & - & 0.231 & 0.302 & 0.550 \\
China, P.R.: Hong Kong & - & - & 0.782 & 0.792 \\
China, P.R.: Taiwan & - & 0.302 & 0.233 & 0.241 \\
Egypt & 0.390 & 0.304 & 0.178 & 0.183 \\
India & 0.112 & 0.112 & 0.133 & - \\
Indonesia & 0.017 & 0.009 & - & 0.104 \\
Korea & 0.493 & 0.444 & 0.858 & 1.023 \\
Kuwait & 0.197 & 0.058 & 0.078 & 0.080 \\
Malaysia & 0.130 & 0.159 & 0.179 & 0.144 \\
Mexico & 0.117 & 0.103 & 0.083 & 0.062 \\
Philippines & 0.060 & 0.028 & 0.043 & 0.051 \\
Romania & 0.116 & 0.026 & 0.054 & 0.071 \\
Russia & - & - & 0.303 & 0.355 \\
Singapore & 0.359 & 0.289 & 0.746 & - \\
South Africa & 0.146 & 0.074 & 0.076 & 0.065 \\
Thailand & 0.075 & 0.170 & 0.199 & 0.198 \\
Turkey & 0.099 & 0.126 & 0.186 & 0.149 \\
Ukraine & - & - & 0.193 & 0.184 \\
\hline
\end{tabular}

Source: Calculated based on IMF (2005)

\subsection{Travel services}

The economic significance for developing countries of another major services export is travel 
services. Travel service exports receipts cover all the expenses of tourists and other travellers during their trips abroad. In most developing countries a large share of travel service exports accrues directly or indirectly to foreign agents supplying the services and goods acquired by tourists and other travellers, as well as the other inputs needed for overall functioning of the service. Initial evidence shows that tourism has emerged in many developing countries as a powerful and fast-growing foreign exchange provider, and in several cases as the only vital non-traditional sector.

Table 5(a)

\begin{tabular}{l|c|c|c|c} 
Exports of travel services & \multicolumn{3}{r}{ (US\$ billion) } \\
\hline Country & 1981 & 1991 & 2001 & 2004 \\
\hline \hline Argentina & 0.413 & 0.782 & 2.642 & 2.563 \\
Brazil & 0.242 & 1.002 & 1.731 & 3.222 \\
China, P.R.: Mainland & & 2.346 & 17.792 & 25.739 \\
China,P.R.: Hong Kong & & & 5.945 & 8.999 \\
China, P.R.: Taiwan & & 2.017 & 4.335 & 4.040 \\
Egypt & 0.418 & 1.373 & 3.800 & 6.125 \\
India & 1.279 & 1.842 & 3.198 & \\
Indonesia & 0.228 & 2.515 & 5.276 & 4.798 \\
Korea & 0.448 & 2.856 & 6.384 & 5.713 \\
Malaysia & 0.387 & 1.783 & 6.863 & 8.198 \\
Mexico & 3.334 & 5.959 & 8.401 & 10.753 \\
Philippines & 0.344 & 0.570 & 1.723 & 2.012 \\
Russia & & & 3.572 & 5.225 \\
Singapore & 1.792 & 4.616 & 4.619 & \\
South Africa & 1.472 & 1.849 & 2.569 & 6.322 \\
Thailand & 0.983 & 4.537 & 7.075 & 10.043 \\
Turkey & 0.380 & 2.654 & 8.090 & 15.888 \\
\hline Souce:Cal & & & &
\end{tabular}

Source: Calculated based on IMF (2005)

The largest exporter of travel services among developing countries is China(Table 5(a)), where the sector underwent an extraordinary fast growth during the 1990s. In 2004, China earned about US\$ 26 billion from travel services, which was mere US\$ 2 billion in 1991. Next comes, Turkey, Thailand, and Hong Kong from developing Asia which also achieved robust growth in exports in travel services during 1991 to 2004. In Asia, travel service is a major export earning sector for China, Turkey, Philippines, Malaysia and Thailand, where over 40\% of total services exports have come from this sector in recent years (Table 5(b)). In Africa, travel service exports contribute over $70 \%$ in case of South Africa and $43 \%$ in case of Egypt. Among the Latin American countries, Argentina and Mexico also earn a large portion of total service exports from travel services. In the case of Brazil, $1 / 4$ of total earnings from service 
exports came from travel services in 2004. In terms of travel services contribution to total services exports, Mexico with over $77 \%$ of services exports from travel ranks the top position among developing economies.

Table 5(b)

Share of travel services in country's total services exports

\begin{tabular}{l|c|c|c|c}
\hline Country & 1981 & 1991 & 2001 & 2004 \\
\hline \hline Argentina & 24.068 & 32.475 & 57.095 & 49.093 \\
Brazil & 10.684 & 30.190 & 18.565 & 25.605 \\
China, P.R.: Mainland & - & 33.615 & 53.375 & 41.226 \\
China,P.R.:Hong Kong & - & - & 14.452 & 16.316 \\
China, P.R.: Taiwan & - & 23.808 & 21.789 & 15.674 \\
Egypt & 16.465 & 20.242 & 42.025 & 43.145 \\
India & 45.707 & 37.388 & 18.447 & - \\
Indonesia & 50.780 & 89.121 & 95.928 & 27.226 \\
Korea & 14.588 & 28.517 & 21.972 & 13.790 \\
Malaysia & 29.396 & 40.765 & 47.481 & 48.891 \\
Mexico & 66.907 & 67.189 & 66.141 & 76.786 \\
Philippines & 19.207 & 15.599 & 54.733 & 49.061 \\
Russia & - & - & 31.216 & 25.754 \\
Singapore & 24.944 & 33.394 & 15.870 & - \\
South Africa & 57.259 & 57.940 & 55.245 & 70.169 \\
Thailand & 60.974 & 62.391 & 54.325 & 52.746 \\
Turkey & 30.063 & 31.701 & 50.377 & 66.071 \\
\hline
\end{tabular}

Source: Calculated based on IMF (2005)

Nevertheless, China's performance in travel services among developing countries is unmatched. Today, over $1 \%$ of global exports of travel service are contributed by China alone, and if the performance of Hong Kong and Taiwan counted together with China, China's global contribution reaches almost $2 \%$. While exports of travel services from most of the developing countries have gone up during 2001 to 2004 that for Indonesia and Singapore have seen a deceleration.

Table 5(c)

Share of travel services in world total services exports

\begin{tabular}{l|c|c|c|c}
\hline Country & 1981 & 1991 & 2001 & 2004 \\
\hline \hline Argentina & 0.101 & 0.090 & 0.172 & 0.117 \\
Brazil & 0.059 & 0.115 & 0.113 & 0.147 \\
China, P.R.: Mainland & & 0.269 & 1.158 & 1.174 \\
\hline
\end{tabular}




\begin{tabular}{l|l|l|l|l}
\hline China,P.R.: Hong Kong & & & 0.387 & 0.410 \\
China, P.R.: Taiwan & & 0.231 & 0.282 & 0.184 \\
Egypt & 0.103 & 0.158 & 0.247 & 0.279 \\
India & 0.314 & 0.211 & 0.208 & \\
Indonesia & 0.056 & 0.289 & 0.343 & 0.219 \\
Korea & 0.110 & 0.328 & 0.415 & 0.261 \\
Malaysia & 0.095 & 0.205 & 0.447 & 0.374 \\
Mexico & 0.819 & 0.684 & 0.547 & 0.490 \\
Philippines & 0.085 & 0.065 & 0.112 & 0.092 \\
Russia & & & 0.232 & 0.238 \\
Singapore & 0.440 & 0.530 & 0.301 & \\
South Africa & 0.362 & 0.212 & 0.167 & 0.288 \\
Thailand & 0.241 & 0.520 & 0.460 & 0.458 \\
Turkey & 0.093 & 0.304 & 0.526 & 0.725 \\
\hline Source Cal
\end{tabular}

Source: Calculated based on IMF (2005)

\subsection{Communication services}

Communication services are among the fastest growing traded service sectors in the world. As opposed to transport and travel services, which rely mostly on mature technologies, communication services are among the most high-technology intensive economic activities. However, major exporters from developing countries are not a lot, and most of them hold a negligible share of the world export market (Table 6(c)). We found that communication services contribute a very negligible share to a country's total service exports in many developing countries (Table (6b)).

Table 6(a)

Exports of communication services

(US\$ billion)

\begin{tabular}{l|c|c|c|c}
\hline Country & 1981 & 1991 & 2001 & 2004 \\
\hline \hline Argentina & - & - & 0.187 & 0.183 \\
Brazil & - & - & 0.242 & 0.243 \\
China, P.R.: Mainland & - & 0.221 & 0.271 & 0.440 \\
China, P.R.:Hong Kong & - & - & 0.505 & 0.852 \\
China, P.R.: Taiwan & - & 0.377 & 0.264 & 0.333 \\
Egypt & - & - & 0.232 & 0.405 \\
India & - & - & 1.104 & - \\
Indonesia & - & - & 0.085 & 0.835 \\
Korea & 0.036 & 0.353 & 0.398 & 0.401 \\
Malaysia & - & - & 0.242 & 0.390 \\
Mexico & - & - & 0.787 & 0.423 \\
\hline
\end{tabular}




\begin{tabular}{l|c|c|c|c}
\hline Philippines & - & - & 0.328 & 0.485 \\
Romania & - & - & 0.135 & 0.296 \\
Russia & - & - & 0.437 & 0.471 \\
South Africa & 0.044 & 0.044 & 0.054 & 0.069 \\
Thailand & - & - & 0.109 & 0.201 \\
Turkey & - & - & - & 0.346 \\
\hline
\end{tabular}

Source: Calculated based on IMF (2005)

Table 6(b)

Share of communication services in country's total services exports (\%)

\begin{tabular}{l|c|c|c|c}
\hline Country & 1981 & 1991 & 2001 & 2004 \\
\hline \hline Argentina & - & - & 4.035 & 3.496 \\
Brazil & - & - & 2.594 & 1.934 \\
China, P.R.: Mainland & - & 3.167 & 0.813 & 0.705 \\
China,P.R.: Hong Kong & - & - & 1.228 & 1.545 \\
China, P.R.: Taiwan & - & 4.450 & 1.327 & 1.292 \\
Egypt & - & - & 2.567 & 2.851 \\
India & - & - & 6.367 & - \\
Indonesia & - & - & 1.545 & 4.740 \\
Korea & 1.180 & 3.529 & 1.368 & 0.968 \\
Malaysia & - & - & 1.677 & 2.329 \\
Mexico & - & - & 6.198 & 3.018 \\
Philippines & - & - & 10.419 & 11.826 \\
Romania & - & - & 6.644 & 8.190 \\
Russia & - & - & 3.815 & 2.320 \\
South Africa & 1.695 & 1.393 & 1.153 & 0.766 \\
Thailand & - & - & 0.836 & 1.057 \\
Turkey & - & - & - & 1.439 \\
\hline
\end{tabular}

Source: Calculated based on IMF (2005)

Table 6(c)

Share of communication services in world total services exports $\quad(\%)$

\begin{tabular}{l|c|c|c|c}
\hline Country & 1981 & 1991 & 2001 & 2004 \\
\hline \hline Argentina & - & - & 0.012 & 0.008 \\
Brazil & - & - & 0.016 & 0.011 \\
China, P.R.: Mainland & - & 0.025 & 0.018 & 0.020 \\
China, P.R.: Hong Kong & - & & 0.033 & 0.039 \\
China, P.R.: Taiwan & - & 0.043 & 0.017 & 0.015 \\
\hline
\end{tabular}




\begin{tabular}{l|c|c|c|c}
\hline Egypt & - & - & 0.015 & 0.018 \\
India & - & - & 0.072 & - \\
Indonesia & - & - & 0.006 & 0.038 \\
Korea & 0.009 & 0.041 & 0.026 & 0.018 \\
Malaysia & - & - & 0.016 & 0.018 \\
Mexico & - & - & 0.051 & 0.019 \\
Philippines & - & - & 0.021 & 0.022 \\
Romania & - & - & 0.009 & 0.013 \\
Russia & - & - & 0.028 & 0.021 \\
South Africa & 0.011 & 0.005 & 0.003 & 0.003 \\
Thailand & - & - & 0.007 & 0.009 \\
Turkey & - & - & - & 0.016 \\
\hline
\end{tabular}

Source: Calculated based on IMF (2005)

In the late 1990s, developing countries exporters appear to have fared poorly. The exception is India, the only developing country which has witnessed exports of over US\$ 1 billion in communication services during 2001 to 2004 (Table 6(a)). Indonesia has also done well in exporting communication services in recent years. In terms of volume of exports, on one hand, most of the Asian countries have achieved higher growth in exports of communication services during 2001-2004, whereas, on the other, Argentina and Mexico, from Latin America, have witnessed negative growth in exports of communication services. Performance of African countries was also lacklustre in exports of communication services during 2001 to 2004.

\subsection{Construction services}

The construction sector is extremely important for developing countries, but the overall presence of developing countries in international markets for construction services is scare. There are, however, three significant exceptions. China, Russia and Turkey are three major exporters of construction services. Exports of construction services from China and Russia have recorded about US\$ 1.5 billion in 2004, whereas exports of construction services from Turkey have touched almost US\$ 1 billion in 2004 (Table 7(a)). Exports of construction services from other developing countries are very negligible.

Table 7(a)

Exports of construction services

(US\$ billion)

\begin{tabular}{l|c|c|c}
\hline Country & 1991 & 2001 & 2004 \\
\hline \hline Argentina & - & - & 0.061 \\
Brazil & - & 0.018 & 0.003 \\
\hline
\end{tabular}




\begin{tabular}{l|c|c|c}
\hline China, P.R.: Mainland & - & 0.830 & 1.467 \\
China, P.R.: Hong Kong & - & 0.411 & 0.378 \\
China, P.R.: Taiwan & 0.092 & 0.099 & 0.152 \\
Egypt & - & 0.141 & 0.406 \\
Indonesia & - & & 0.463 \\
Korea & - & 0.082 & 0.038 \\
Malaysia & - & 0.338 & 0.327 \\
Philippines & 0.002 & 0.064 & 0.073 \\
Russia & - & 0.737 & 1.577 \\
Thailand & - & 0.296 & 0.236 \\
Turkey & 0.713 & 0.685 & 0.743 \\
\hline
\end{tabular}

Source: Calculated based on IMF (2005)

Table 7(b)

Share of construction services in country's

total services exports

\begin{tabular}{l|c|c|c}
\hline Country & 1991 & 2001 & 2004 \\
\hline \hline Argentina & - & - & 1.174 \\
Brazil & - & 0.188 & 0.022 \\
China, P.R.: Mainland & - & 2.490 & 2.350 \\
China,P.R.:Hong Kong & - & 0.999 & 0.685 \\
China, P.R.: Taiwan & 1.086 & 0.498 & 0.590 \\
Egypt & - & 1.562 & 2.863 \\
Indonesia & - & - & 2.627 \\
Korea & - & 0.281 & 0.091 \\
Malaysia & - & 2.339 & 1.949 \\
Philippines & 0.055 & 2.033 & 1.780 \\
Romania & - & 2.904 & 3.320 \\
Russia & - & 6.438 & 7.773 \\
Thailand & - & 2.271 & 1.238 \\
Turkey & 8.516 & 4.266 & 3.090 \\
\hline
\end{tabular}

Source: Calculated based on IMF (2005)

Table 7(c)

Share of construction services in world

total services exports

\begin{tabular}{l|c|c|c}
\hline Country & 1991 & 2001 & 2004 \\
\hline \hline Argentina & - & - & 0.003 \\
Brazil & - & 0.001 & 0.000 \\
\hline
\end{tabular}




\begin{tabular}{l|c|c|c}
\hline China, P.R.: Mainland & - & 0.054 & 0.067 \\
China,P.R.: Hong Kong & - & 0.027 & 0.017 \\
China, P.R.: Taiwan & 0.011 & 0.006 & 0.007 \\
Egypt & - & 0.009 & 0.019 \\
Indonesia & - & - & 0.021 \\
Korea & - & 0.005 & 0.002 \\
Malaysia & - & 0.022 & 0.015 \\
Philippines & 0.000 & 0.004 & 0.003 \\
Romania & - & 0.004 & 0.005 \\
Russia & - & 0.048 & 0.072 \\
Thailand & - & 0.019 & 0.011 \\
Turkey & 0.082 & 0.045 & 0.034 \\
\hline
\end{tabular}

Source: Calculated based on IMF (2005)

The brief observations on trade in construction services indicate that exports of construction services during 2001 to 2004 have grown rapidly in transition economies (Russia, Romania, etc.), but the market actually shrank in most of the developing Asian economies except China Mainland and China Taiwan, due mainly to the Asian financial crisis. What follows is that even though developing countries offer the bulk of construction activities, their shares in world exports of construction services are very negligible (Table 7(c)). Except for China, Russia and Turkey, none is yet to make any considerable foray into the world construction services market.

\subsection{Financial and insurance services}

Exports of financial and insurance services have been growing at more than $10 \%$ per annum worldwide during the last two decades, reaching a total volume of almost US\$ 125 billion in 2004. The developing countries are minor payers in international financial markets. Moreover, their exports of financial and insurance services almost stagnated during 1991 to 2004, severely eroding their share of global exports.

Table 8(a)

Exports of financial services $^{\mathrm{a}}$

\begin{tabular}{l|c|c|c|c}
\hline Country & 1981 & 1991 & 2001 & 2004 \\
\hline \hline Argentina & 0.006 & 0.003 & 0.004 & 0.002 \\
Brazil & 0.109 & 0.060 & 0.497 & 0.528 \\
China, P.R.: Mainland & - & 0.342 & 0.326 & 0.475 \\
China, P.R.: Hong Kong & - & - & 4.940 & 4.964 \\
China, P.R.: Taiwan & - & 0.218 & 0.918 & 1.524 \\
Egypt & 0.003 & 0.042 & 0.080 & 0.112 \\
\hline
\end{tabular}




\begin{tabular}{l|c|c|c|c}
\hline India & 0.038 & 0.107 & 0.588 & - \\
Indonesia & - & - & - & 0.305 \\
Korea & - & - & 0.593 & 1.147 \\
Malaysia & 0.001 & 0.003 & 0.375 & 0.453 \\
Mexico & 0.604 & 0.510 & 1.352 & 0.864 \\
Philippines & - & 0.020 & 0.081 & 0.059 \\
Russia & - & - & 0.201 & 0.512 \\
Singapore & 0.064 & 0.114 & 1.845 & - \\
South Africa & 0.326 & 0.181 & 0.323 & 0.360 \\
Thailand & 0.011 & 0.012 & 0.088 & 0.135 \\
Turkey & 0.028 & - & 0.356 & 0.562 \\
\hline
\end{tabular}

Note: a)Including insurance services

Source: Calculated based on IMF (2005)

Table 8(b)

Share of financial services in country's total services exports

$(\%)$

\begin{tabular}{l|c|c|c|c}
\hline Country & 1981 & 1991 & 2001 & 2004 \\
\hline \hline Argentina & 0.350 & 0.125 & - & - \\
Brazil & 4.812 & 1.808 & 1.926 & 0.836 \\
China, P.R.: Mainland & - & 4.900 & 0.681 & 0.610 \\
China, P.R.: Hong Kong & - & - & 1.108 & 0.744 \\
China, P.R.: Taiwan & - & 2.573 & 2.031 & 1.482 \\
Egypt & 0.135 & 0.619 & 0.104 & 0.267 \\
India & 1.346 & 2.165 & 1.627 & - \\
Indonesia & - & - & - & 0.047 \\
Korea & - & - & 0.207 & 0.153 \\
Malaysia & 0.099 & 0.075 & 1.833 & 1.627 \\
Mexico & 12.121 & 5.750 & 10.642 & 6.169 \\
Philippines & - & 0.547 & 1.525 & 0.293 \\
Romania & 4.776 & 3.647 & 1.821 & 0.719 \\
Russia & - & - & 0.633 & 1.191 \\
Singapore & 0.891 & 0.825 & 6.339 & - \\
South Africa & 12.661 & 5.676 & 6.936 & 4.001 \\
Thailand & 0.691 & 0.162 & 0.673 & 0.710 \\
Turkey & 2.239 & - & 0.156 & 1.139 \\
\hline
\end{tabular}

Note: Including insurance services

Source: Calculated based on IMF (2005) 
Table 8(c)

Share of financial services in world total services exports

\begin{tabular}{l|c|c|c|c}
\hline Country & 1981 & 1991 & 2001 & 2004 \\
\hline \hline Argentina & 0.0015 & 0.0003 & 0.0003 & 0.0001 \\
Brazil & 0.0268 & 0.0069 & 0.0323 & 0.0241 \\
China, P.R.: Mainland & - & 0.0392 & 0.0212 & 0.0216 \\
China, P.R.:Hong Kong & - & - & 0.3214 & 0.2264 \\
China, P.R.: Taiwan & - & 0.0250 & 0.0597 & 0.0695 \\
Egypt & 0.0008 & 0.0048 & 0.0052 & 0.0051 \\
India & 0.0092 & 0.0122 & 0.0383 & - \\
Indonesia & - & - & - & 0.0139 \\
Korea & - & - & 0.0386 & 0.0523 \\
Malaysia & 0.0003 & 0.0004 & 0.0244 & 0.0206 \\
Mexico & 0.1484 & 0.0585 & 0.0880 & 0.0394 \\
Philippines & - & 0.0023 & 0.0053 & 0.0027 \\
Romania & 0.0128 & 0.0028 & 0.0085 & 0.0046 \\
Russia & - & - & 0.0131 & 0.0233 \\
Singapore & 0.0157 & 0.0131 & 0.1201 & - \\
South Africa & 0.0800 & 0.0208 & 0.0210 & 0.0164 \\
Thailand & 0.0027 & 0.0013 & 0.0057 & 0.0062 \\
Turkey & 0.0070 & - & 0.0232 & 0.0256 \\
\hline
\end{tabular}

Note: Including insurance services

Source: Calculated based on IMF (2005)

Among major developing countries, Hong Kong, Singapore, Korea and Taiwan have achieved over US\$ 1 billion in exports of financial and insurance services in 2004 (Table 8(a)). Exports of financial services from Hong Kong is quite noteworthy, the country has achieved about US\$ 5 billion in exports of financial services in 2004. Except Mexico, exports of financial services from Latin American countries are very negligible. India's performance in exports of financial services is satisfactory. In 2003, exports of financial services from India have reached almost US\$ 1 billion, which was a mere US\$100 million in 1991.

Exports of financial services from developing countries are yet to make any considerable presence in world market. Except Hong Kong and Singapore, none has gained any considerable share in world financial services market during 1991 to 2004. To a great extent, contribution of financial and insurance services to their respective home country exports is also very negligible. Even in many major developing countries (e.g. China, Mexico), shares of financial and insurance services to a country's services exports have been decelerating during 2001-2004. 


\subsection{Computer and Information Services}

Computer and information services are one of the fastest growing sectors of developing countries. Aggregate figures indicate that, starting from an almost zero base in the early 1980s, exports of this most modern, dynamic and technology-based services increased extremely fast over the last two decades, maintaining double digit growth rates worldwide also during 2001-2004 and reaching a total value of almost US\$ 50 billion in 2004. The role of developing countries, except India, toward the exports of computer and information services is very marginal. While India has achieved US\$ 11 billion of exports of computer and information services in 2003 (Table 9(a)), touching almost $50 \%$ of country's total exports of services, the other developing countries have no substantial presence in international computer and information services markets. China, however, has witnessed an almost 50\% jump in exporting computer and information services in 2004, compared to 2003, and achieved exports of US\$ 1.64 billion in 2004 (Table 9(a)).

Table 9(a)

Exports of computer and information services

(US\$ billion)

\begin{tabular}{l|c|c|c|c}
\hline Country & 1981 & 1991 & 2001 & 2004 \\
\hline \hline Argentina & & & 0.189 & 0.176 \\
China, P.R.: Mainland & & & 0.461 & 1.637 \\
China,P.R.: Hong Kong & & & 0.154 & 0.245 \\
India & & & 7.407 & - \\
Malaysia & & & 0.176 & 0.349 \\
Russia & & & 0.128 & 0.256 \\
Singapore & & & 0.312 & - \\
\hline
\end{tabular}

Source: Calculated based on IMF (2005)

Table 9(b)

Share of computer and information services in country's total services exports

\begin{tabular}{l|c|c|c|c}
\hline Country & 1981 & 1991 & 2001 & 2004 \\
\hline \hline Argentina & & & 4.083 & 3.377 \\
China, P.R.: Mainland & & & 1.383 & 2.622 \\
China, P.R.: Hong Kong & & & 0.374 & 0.443 \\
India & & & 42.727 & - \\
Malaysia & & & 1.220 & 2.082 \\
Russia & & & 1.119 & 1.261 \\
Singapore & & & 1.072 & - \\
\hline
\end{tabular}

Source: Calculated based on IMF (2005) 
Table 9(c)

Share of computer and information services in world total services exports

\begin{tabular}{l|l|l|l|l}
\hline Country & 1981 & 1991 & 2001 & 2004 \\
\hline \hline Argentina & & & 0.012 & 0.008 \\
China, P.R.: Mainland & & & 0.030 & 0.075 \\
China, P.R.: Hong Kong & & & 0.010 & 0.011 \\
India & & & 0.482 & - \\
Malaysia & & & 0.011 & 0.016 \\
Russia & & & 0.008 & 0.012 \\
Singapore & & & 0.020 & - \\
\hline
\end{tabular}

Source: Calculated based on IMF (2005)

\subsection{Personal, cultural and recreational services}

Exports of personal, cultural and recreational services, which include audiovisual services, have been growing quite strong both from developed and developing countries. During 2001 to 2004, personal, cultural and recreational services have grown over $18 \%$ per annum in developing countries, touching almost the world average. Among the developing countries, Malaysia and Turkey are the top two largest exporters of personal, cultural and recreational services, both achieved over US\$ 1 billion exports of personal, cultural and recreational services in 2004. Performance of Malaysia in exports of personal, cultural and recreational services is outstanding country's exports in this sector has gone up from mere US\$ 0.30 billion in 2001 to over US\$ 1.50 billion in 2004 (Table 10(a)). To date, about 10\% of the country's services exports come from personal, cultural and recreational services in Malaysia. However, none from developing countries has a strong presence in world exports of personal, cultural and recreational services.

While virtually every developing country already has successful service exporters, these success stories are not always reflected in traditional economic analysis. Due to the absence of improved quantitative information on trade in services, developing countries' governments may not be fully aware of the capabilities that exist. Lack of awareness of existing exports can undermine the potential growth of those exports. Therefore, it is apparent that available statistical information is particularly scant and is inadequate in the case of personal, cultural and recreational services, and thus its information contribution to evaluate the role of developing countries in the world market for this sector is limited.

Table 10(a)

Exports of personal, cultural and recreational services (US\$ billion)

\begin{tabular}{l|l|l|l|l}
\hline Country & 1981 & 1991 & 2001 & 2004 \\
\hline \hline Argentina & & & 0.038 & 0.129 \\
\hline
\end{tabular}




\begin{tabular}{|c|c|c|}
\hline China,P.R.: Hong Kong & 0.099 & 0.290 \\
\hline Korea & 0.138 & 0.128 \\
\hline Malaysia & 0.029 & 1.657 \\
\hline Mexico & 0.318 & 0.358 \\
\hline Romania & 0.067 & 0.214 \\
\hline Russia & 0.085 & 0.164 \\
\hline Turkey & 1.072 & 1.419 \\
\hline
\end{tabular}

Source: Calculated based on IMF (2005)

Table 10(b)

Share of personal, cultural and recreational services in country's total services exports

\begin{tabular}{l|l|l|l|l} 
services exports & 1981 & 1991 & 2001 & 2004 \\
\hline Country & & & 0.813 & 2.471 \\
\hline \hline Argentina & & & 0.241 & 0.525 \\
\hline China,P.R.: Hong Kong & & & 0.476 & 0.308 \\
Korea & & & 0.202 & 9.882 \\
Malaysia & & & 2.503 & 2.554 \\
Mexico & & 3.297 & 5.921 \\
Romania & & 0.739 & 0.807 \\
Russia & & & 6.675 & 5.901 \\
Turkey & & & \multicolumn{3}{|c}{} \\
\hline
\end{tabular}

Source: Calculated based on IMF (2005)

Table 10(c)

Share of personal, cultural and recreational services in world total services exports

\begin{tabular}{l|l|l|l|l}
\hline Services exports & 1981 & 1991 & 2001 & 2004 \\
\hline \hline Country & & & 0.002 & 0.006 \\
Argentina & & & 0.006 & 0.013 \\
Kina,P.R.: Hong Kong & & & 0.009 & 0.006 \\
Malaysia & & & 0.002 & 0.076 \\
Mexico & & & 0.021 & 0.016 \\
Romania & & & 0.004 & 0.010 \\
Russia & & & 0.006 & 0.007 \\
Turkey & & & 0.070 & 0.065 \\
\hline
\end{tabular}

Source: Calculated based on IMF (2005)

In many sectors, a strong domestic market plays a key role as the platform for developing export 
capacity. This pattern is evident in telecommunications, audiovisuals, distribution, transport and related services and higher education services - and even, in some cases, in e-commerce related sectors. Normally, countries tend to follow a pattern: serving the domestic market first, and then once the critical size had been reached, taking steps to exports except ICT enabled and related services where geography is less important and tourism, where a country may aim at global markets initially. Needless to say, in order to gain higher market access, developing countries need to take steps to specialize in service sectors which will not only enhance their domestic service markets but also strengthen export capacity.

\section{Export competitiveness of developing countries in trade in services}

As in manufacturing, the most important potential contribution of competitiveness of services sector is the level and scale of technology. Services industries differ greatly in their hard and soft technology mix. Sectors such as air and rail transport, communications, broadcasting, electricity, gas and water are highly capital-intensive, whereas construction services is relatively labourintensive. Nevertheless, most of the developing countries have registered a considerable expansion of total services trade in recent years, but very few of them have been able to sustain their services trade specialisation and not all are having rising competitiveness in services trade. In general, as in trade in goods, developing countries as service exporters benefit from labour and natural resource abundance. Therefore, in their initial years of development, these countries gain comparative advantage in labour-intensive services such as construction services, tourism, data processing, and so forth, as countries grow their production and trade specialisation patterns also evolve towards higher-skilled and technologically advanced services.

To understand the pattern of services trade specialisation, and to know whether or not the sector is globally competitive, we attempt to measure the relative competitiveness of services trade with the help of the Revealed Comparative Advantage (RCA) ${ }^{10}$ of different services trade sectors. If the estimated RCA index of a sector is found to be greater than one, then it is considered as globally competitive. Appendix A shows the estimated Revealed Comparative Advantage (RCA) Index for selected developing countries for the period 1991 to 2004. This index shows the country's specialisation in individual service sectors and therefore their comparative advantage. Table 11 presents a list of countries having revealed a comparative advantage in recent years. Some observations with plausible policy implications are worth noting ${ }^{11}$.

\footnotetext{
${ }^{10}$ The RCA has been calculated based on following equation: $\mathrm{RCA}=\left(\mathrm{X}_{\mathrm{iw}}{ }^{\mathrm{k}} / \mathrm{X}_{\mathrm{iw}}{ }^{\mathrm{Ek}}\right) /\left(\mathrm{X}_{\mathrm{w}}{ }^{\mathrm{k}} / \mathrm{X}_{\mathrm{w}}{ }_{\mathrm{w}} \mathrm{kk}\right)$, where $\mathrm{X}_{\mathrm{iw}}{ }^{\mathrm{k}}$ is country i's world exports of services $k, X_{i w}{ }^{2 k}$ is country i's exports of goods and services, $X_{w}{ }^{k}$ is world exports of services $\mathrm{k}$, and $\mathrm{X}_{\mathrm{w}}^{\mathrm{Lk}}$ is world exports of goods and services. If the estimated RCA index of a sector is found to be greater than one, then it is considered as globally competitive (Ballasa, 1965).

${ }^{11}$ As noted in Box 1, it should be noted that these results have to be interpreted with care given the numerous inconsistencies in the underlying statistical databases.
} 
Table 11

Countries with Revealed Comparative Advantage ${ }^{a}$

\begin{tabular}{c|c|c}
\hline Category of Services & Sector & Countries with RCA>1 \\
\hline \hline $\begin{array}{c}\text { Labour and resource } \\
\text { Labour and resource } \\
\text { intensive }\end{array}$ & Transport & $\begin{array}{c}\text { Argentina, China Hong Kong, Egypt, India, } \\
\text { Korea, Kuwait, Romania, Russia, Singapore, } \\
\text { Thailand, Turkey, Ukraine }\end{array}$ \\
\hline $\begin{array}{c}\text { Labour intensive } \\
\text { Skill and technology } \\
\text { intensive }\end{array}$ & Construction & $\begin{array}{c}\text { Argentina, China Mainland, Egypt, India, } \\
\text { Malaysia, Mexico, Philippines, South Africa, } \\
\text { Thailand, Turkey }\end{array}$ \\
\hline $\begin{array}{c}\text { Skill and technology } \\
\text { intensive }\end{array}$ & $\begin{array}{c}\text { Computer and } \\
\text { information services } \\
\text { Russia, Thailand, Turkey, Ukraine }\end{array}$ \\
\hline $\begin{array}{c}\text { Skill and technology } \\
\text { intensive }\end{array}$ & Financial services & $\begin{array}{c}\text { Argentina, Brazil, Egypt, India, Indonesia, } \\
\text { Philippines, Romania, Turkey, Ukraine }\end{array}$ \\
\hline Miscelleneous & $\begin{array}{c}\text { Personal, cultural and } \\
\text { recreational services }\end{array}$ & Argentina, India, Romania \\
\hline
\end{tabular}

Notes: a) Considers RCA ( $\geq 1$ ) for the period 2001 to 2004 .

b) Refer Appendix 1 for the RCA scores.

Results reported in Table 11 shows that except Taiwan (China), all reported developing countries have a comparative advantage in one or many services trade sectors. By contrast, Taiwan has shown no comparative advantage in exporting trade in services during 1981 to 2004. However, none yet has attained comparative advantage in all the sectors, and at the same time, there are some countries which have gained comparative advantages in a single sector: Brazil and Indonesia in exporting communication services; Korea and Kuwait in exporting transport services, and South Africa in exporting travel services. While India has a comparative advantage in exporting computer and information services due to its relatively rich IT sector, or the transport sector in Singapore, services trade in much of Africa, except South Africa in travel services, is often very poor.

Developing countries seem to be particularly successful in certain sectors, such as port and shipping services, audiovisual services, construction services and health services. For example in some services - shipping and port services - developing countries are world players. In general, developing countries seem to be relatively specialised in transport and travel services which both are labour and natural resource intensive.

Therefore, developing countries have a clear comparative advantage in labour-intensive services 
such as construction services and data-processing, including — in a growing number of areas - at the higher skilled end of the chain. Technological advances in telecommunication and computer industries have allowed developing countries endowed with a well-educated and cost-competitive workforce to produce and export computer and related services worldwide. The spectacular Indian performance of the last few two decades is the most notable and documented case.

\section{Conclusions}

Total services trade registered a dynamic evolution in almost all developing countries. The share of developing countries in world services trade increased progressively, sharing $1 / 4$ of world trade in services at present. However, the gap between developed and developing countries in services exports has been widening. Developed countries are net exporters of services whereas developing countries are net importers.

Concerning the sector distribution of trade in services, the relative importance of different types of services activities varies across developing countries. Transport and travel services represent the dominant export activity for developing countries. Transport services account for significant shares of services exports (over 50\%) in Korea, Kuwait and Ukraine, while Mexico and Indonesia are characterised by low and declining transport exports.

Most of the developing countries are relatively specialised in transport and travel services. This comparative advantage in (low-skilled) labour intensive services (construction services) and (in some cases) natural-endowment-intensive services (transportation, travel services) confirms expectations based on trade theories according to which the direction and nature of factor flows are determined by differences in endowment and relative costs. The disadvantage in service transactions which involve the movement of higher skilled personnel could further confirm the expected gap in export capacity know-how-intensive services of developing countries.

Developing countries successfully export a variety of services to both developed and developing countries. A relatively limited number of developing countries seem to be heavily involved in services exports trade across a range of sectors. This fact might suggest that service exports, on a large international level, are associated with higher levels of development and that not all developing countries are yet in a position to be large-scale exporters.

Host-country policies on services are equally important to development gains. National policymaking in services affects the ability of a country to attract desired types of FDI and to extract benefits from it. Most FDI in services is market-seeking in nature, but as services become more tradable, the scope for efficiency-seeking FDI - and thus for associated policies - is expanding. Therefore, a general challenge facing policy-makers is to strike the right balance between economic efficiency and other policy concerns.

Services can offer a series of potential benefits. They can provide a stable, predictable and transparent enabling framework for attracting investment and benefiting from it. At the same time, the optimal realization of these potential benefits remains a challenge. This challenge is particularly crucial for developing countries for a number of reasons. First, in many of the developing countries, 
the service sector is at an early stage of development and is rapidly evolving. Second, certain services sectors are particularly sensitive, as they are deeply embedded in a country's social, cultural and political fabric. Third, some developing countries do not yet have optimal regulatory systems in place, and policy-makers are experimenting with liberalization and regulation, with a view to building a more competitive services sector through FDI and other means. Therefore, it is important for developing countries to find a development-oriented balance when formulating international policies for services sector.

Finally, rising trade asymmetry between developed and developing countries calls for better policy formulation not only for removal of the widening trade gap but also for strengthening services export capacity in developing countries. The importance of services trade from developing countries is therefore required to be reflected in the global policy agenda - ranging from liberalisation to promotional efforts to expansion of services trade at international levels. Given the policy reforms undertaken by developing and developed countries unilaterally and in the context of WTO, the environment today appears to be more conducive than ever before for mutually beneficial cooperation. However, the realization of this potential will depend on how the developed world liberalises its service trade sectors and how developing countries strengthen their services export capacity.

\section{Acknowledgement}

An earlier version of the paper was presented at the WTO/ESCAP/ARTNeT Advanced Regional Seminar on 'Multilateral Negotiations in Services for Asian and Pacific Economies' held at Calcutta, India, during 19-21 September 2006. Author is particularly grateful to Dr. Nagesh Kumar, Dr. Mia Mikic and two anonymous referees for their insightful comments. The usual disclaimers apply.

\section{Appendix}

Estimated scores of revealed comparative advantages

\begin{tabular}{l|l|c|c|c}
\hline Country & Sector & 1991 & 2001 & 2004 \\
\hline Argentina & Transport & 3.21 & 1.06 & 1.04 \\
\hline & Travel & 1.50 & 2.25 & 1.78 \\
\hline & Communications & & 2.10 & 1.66 \\
\hline & Construction & & & 0.84 \\
\hline & Computer and information services & & 1.40 & 1.03 \\
\hline & Financial services (includinginsurance) & 0.04 & 0.01 & 0.01 \\
\hline Brazil & Personal, cultural and recreational services & & 1.09 & 2.31 \\
\hline & Transport & 1.62 & 0.78 & 0.78 \\
\hline & Travel & 0.79 & 0.68 & 0.81 \\
\hline & Communications & & 1.25 & 0.86 \\
\hline
\end{tabular}




\begin{tabular}{|c|c|c|c|c|}
\hline & Construction & & 0.14 & 0.02 \\
\hline & Computer and information services & & 0.09 & 0.11 \\
\hline & Financial services & 0.36 & 0.84 & 0.59 \\
\hline & Personal, cultural and recreational services & & 0.77 & 0.34 \\
\hline \multirow[t]{7}{*}{ China Mainland } & Transport & 0.99 & 0.57 & \\
\hline & Travel & 0.82 & 1.58 & \\
\hline & Communications & 3.48 & 0.32 & \\
\hline & Construction & & 1.44 & \\
\hline & Computer and information services & & 0.36 & \\
\hline & Financial services & 0.91 & 0.12 & \\
\hline & Personal, cultural and recreational services & & 0.08 & \\
\hline \multirow[t]{7}{*}{ China, Hong Kong } & Transport & & 1.93 & \\
\hline & Travel & & 0.69 & \\
\hline & Communications & & 0.77 & \\
\hline & Construction & & 0.93 & \\
\hline & Computer and information services & & 0.16 & \\
\hline & Financial services & & 1.63 & \\
\hline & Personal, cultural and recreational services & & 0.39 & \\
\hline \multirow[t]{7}{*}{ China, Taiwan } & Transport & 1.21 & 0.93 & 0.97 \\
\hline & Travel & 0.66 & 0.81 & 0.55 \\
\hline & Communications & 5.55 & 0.65 & 0.64 \\
\hline & Construction & 0.62 & 0.36 & 0.42 \\
\hline & Computer and information services & & 0.25 & 0.13 \\
\hline & Financial services & 0.54 & 0.74 & 0.93 \\
\hline & Personal, cultural and recreational services & & 0.23 & 0.19 \\
\hline \multirow[t]{7}{*}{ Egypt } & Transport & 9.83 & 7.67 & 6.79 \\
\hline & Travel & 3.61 & 7.67 & 7.73 \\
\hline & Communications & & 6.17 & 7.22 \\
\hline & Construction & & 5.57 & 10.22 \\
\hline & Computer and information services & & 0.39 & 0.35 \\
\hline & Financial services & 0.84 & 0.69 & 0.63 \\
\hline & Personal, cultural and recreational services & & 1.29 & 2.52 \\
\hline \multirow[t]{7}{*}{ India } & Transport & 1.68 & 1.25 & \\
\hline & Travel & 2.24 & 1.40 & \\
\hline & Communications & & 6.37 & \\
\hline & Construction & & 0.56 & \\
\hline & Computer and information services & & 28.19 & \\
\hline & Financial services & 0.99 & 1.11 & \\
\hline & Personal, cultural and recreational services & & & \\
\hline Indonesia & Transport & 0.10 & & \\
\hline
\end{tabular}




\begin{tabular}{|c|c|c|c|c|}
\hline & Travel & 2.17 & 2.26 & \\
\hline & Communications & & 0.48 & \\
\hline & Construction & & & \\
\hline & Computer and information services & & & \\
\hline & Financial services & & & \\
\hline & Personal, cultural and recreational services & & & \\
\hline \multirow[t]{7}{*}{ Korea } & Transport & 1.84 & 2.71 & 2.79 \\
\hline & Travel & 0.96 & 0.95 & 0.53 \\
\hline & Communications & 5.36 & 0.78 & 0.53 \\
\hline & Construction & & 0.24 & 0.07 \\
\hline & Computer and information services & 0.38 & 0.02 & 0.02 \\
\hline & Financial services & 0.05 & 0.38 & 0.48 \\
\hline & Personal, cultural and recreational services & & 0.69 & 0.34 \\
\hline \multirow[t]{7}{*}{ Kuwait } & Transport & 9.42 & 2.48 & 1.81 \\
\hline & Travel & 3.35 & 0.15 & 0.14 \\
\hline & Communications & & & \\
\hline & Construction & & & \\
\hline & Computer and information services & & & \\
\hline & Financial services & & 0.46 & 0.27 \\
\hline & Personal, cultural and recreational services & & & \\
\hline \multirow[t]{7}{*}{ Malaysia } & Transport & 1.40 & 0.99 & \\
\hline & Travel & 1.27 & 1.78 & \\
\hline & Communications & & 0.83 & \\
\hline & Construction & & 1.72 & \\
\hline & Computer and information services & & 0.40 & \\
\hline & Financial services & 0.02 & 0.42 & \\
\hline & Personal, cultural and recreational services & & 0.25 & \\
\hline \multirow[t]{7}{*}{ Mexico } & Transport & 0.68 & 0.28 & 0.25 \\
\hline & Travel & 3.18 & 1.30 & 1.45 \\
\hline & Communications & & 1.61 & 0.81 \\
\hline & Construction & & & 0.00 \\
\hline & Computer and information services & & & 0.00 \\
\hline & Financial services & 2.07 & 0.91 & 0.52 \\
\hline & Personal, cultural and recreational services & & 1.66 & 1.40 \\
\hline \multirow[t]{6}{*}{ Philippines } & Transport & 0.76 & 0.68 & 0.94 \\
\hline & Travel & 1.26 & 1.28 & 1.26 \\
\hline & Communications & & 3.21 & 4.29 \\
\hline & Construction & & 0.93 & 0.91 \\
\hline & Computer and information services & & 0.14 & 0.17 \\
\hline & Financial services & 0.34 & 0.26 & 0.17 \\
\hline
\end{tabular}




\begin{tabular}{|c|c|c|c|c|}
\hline & Personal, cultural and recreational services & & 0.38 & 0.16 \\
\hline \multirow[t]{7}{*}{ Romania } & Transport & 1.76 & 2.27 & 2.11 \\
\hline & Travel & 0.81 & 0.72 & 0.51 \\
\hline & Communications & & 3.52 & 4.23 \\
\hline & Construction & & 2.29 & 2.42 \\
\hline & Computer and information services & & 0.86 & 1.22 \\
\hline & Financial services & 1.06 & 1.12 & 0.45 \\
\hline & Personal, cultural and recreational services & & 4.47 & 6.27 \\
\hline \multirow[t]{7}{*}{ Russia } & Transport & & 1.50 & 1.42 \\
\hline & Travel & & 0.83 & 0.71 \\
\hline & Communications & & 1.34 & 0.90 \\
\hline & Construction & & 3.35 & 4.27 \\
\hline & Computer and information services & & 0.26 & 0.29 \\
\hline & Financial services & & 0.20 & 0.31 \\
\hline & Personal, cultural and recreational services & & 0.66 & 0.65 \\
\hline \multirow[t]{7}{*}{ Singapore } & Transport & 1.35 & 2.80 & \\
\hline & Travel & 1.75 & 0.81 & \\
\hline & Communications & & & \\
\hline & Construction & & 0.67 & \\
\hline & Computer and information services & & 0.48 & \\
\hline & Financial services & 0.33 & 1.40 & \\
\hline & Personal, cultural and recreational services & & 0.12 & \\
\hline \multirow[t]{7}{*}{ South Africa } & Transport & 0.94 & 1.27 & 0.93 \\
\hline & Travel & 1.92 & 2.01 & 2.86 \\
\hline & Communications & 2.07 & 0.56 & 0.49 \\
\hline & Construction & & & \\
\hline & Computer and information services & & & \\
\hline & Financial services & 1.43 & 1.09 & 0.81 \\
\hline & Personal, cultural and recreational services & & & \\
\hline \multirow[t]{7}{*}{ Thailand } & Transport & 1.62 & 1.45 & 1.37 \\
\hline & Travel & 3.50 & 2.41 & 2.37 \\
\hline & Communications & & 0.49 & 0.67 \\
\hline & Construction & & 1.98 & 1.11 \\
\hline & Computer and information services & & & \\
\hline & Financial services & 0.07 & 0.13 & 0.14 \\
\hline & Personal, cultural and recreational services & & & \\
\hline \multirow[t]{4}{*}{ Turkey } & Transport & 1.95 & 2.22 & 1.40 \\
\hline & Travel & 3.33 & 4.54 & 5.08 \\
\hline & Communications & & & 1.56 \\
\hline & Construction & 18.58 & 7.52 & 4.74 \\
\hline
\end{tabular}




\begin{tabular}{l|l|c|c|c}
\hline & Computer and information services & & & \\
\hline & Financial services & & 0.86 & 0.80 \\
\hline & Personal, cultural and recreational services & & 20.28 & 13.15 \\
\hline Ukraine & Transport & & 5.39 & 3.81 \\
\hline & Travel & & 0.75 & 0.80 \\
\hline & Communications & & 1.61 & 1.24 \\
\hline & Construction & & 0.69 & 1.02 \\
\hline & Computer and information services & & 0.08 & 0.18 \\
\hline & Financial services & & 0.14 & 0.13 \\
\hline & Personal, cultural and recreational services & & 0.13 & 0.22 \\
\hline
\end{tabular}

\section{References}

Adlung, R. 2006. Measuring Trade in Services: Recent Developments, Presentation Made at the WTO/ESCAP/ARTNeT Advanced Regional Seminar on 'Multilateral Negotiations in Services for Asian and Pacific Economies' held at Calcutta, India, 19-21 September.

Balassa, B. 1965. Trade liberalization and 'revealed' comparative advantage, The Manchester School of Economic and Social Studies. Vol. 33: 99-123

Charlton, A. H. and Stiglitz. 2005. A development -friendly prioritisation of Doha Round Proposals, The World Economy, Vol. 28, No. 3: 293 - 312.

Chaudhuri, S., Mattoo, A., Self, R. 2004. Moving people to deliver services: How can the WTO help?. Journal of World Trade, Vol. 38, No. 3: 363-393.

Clark, X., David, D. and Micco, A. 2004. Port efficiency, maritime transport costs and bilateral trade, Working Paper 10353, NBER, Cambridge.

Eschenbach, F and Hoekman, B. 2005. Services policy reform and economic growth in transition economies, 1990-2004, Policy Research Working Paper No. 3663, World Bank, Washington D.C.

Fink, C., Mattoo A, and Neagu, I. C. 2002. Trade in international maritime services: How much does policy matter? The World Bank Economic Review, Vol. 16: 451-79.

Fink, C., Mattoo, A. and Neagu, I. C. 2005. Assessing the impact of communication costs on international trade?, Journal of International Economics, Vol. 67: 428 - 445

Gabriele, A. 2004. International trade in services and the evolving position of developing countries, Journal of Economic Integration, Vol. 19, No. 4: 780-803

International Monetary Fund (IMF). 2005. Balance of payments statistics yearbook CD-ROM 2005, Washington, D.C 
Luff, D. 2004. Telecommunications and audio-visual services: considerations for a convergence policy at the World Trade Organisation Level, Journal of World Trade, Vol. 38, No. 6: 1059-1086

Mattoo, A., Rathindran, R. and Subramanian, A. 2006. Measuring services trade liberalization and its impact on economic growth, Journal of Economic Integration, Vol. 21, No. 1: 64 - 97

Organisation for Economic Cooperation and Development (OECD). 2003a. Quantifying the benefits of liberalising trade in services, Paris.

Organisation for Economic Cooperation and Development (OECD). 2003b. Services trade liberalisation: Identifying opportunities and gains, Paris

Organisation for Economic Cooperation and Development (OECD). 2003c. Services trade liberalisation: Identifying opportunities and gains: Key findings, Paris

Organisation for Economic Cooperation and Development (OECD). 2003d. Opening up trade in services: Opportunities and gains for developing countries, Policy Brief, OECD Observer, Paris, August

Organization for Economic Cooperation and Development (OECD). 2005. Growth in services: fostering employment, productivity and innovation, Meeting of the OECD Council at Ministerial Level, Paris

Sung, Keuk-Je. 2004. The Doha Development Agenda and the General Agreement on Trade in services negotiation and regulatory reform in Korea, Journal of International Logistics and Trade, Vol. 2, No. 2: 29-39

United Nations Conference on Trade and Development (UNCTAD). 2004. World investment report 2004: The shift towards services, Geneva.

United Nations Conference on Trade and Development (UNCTAD). 2005. Handbook of statistics CD-ROM 2005, Geneva.

World Bank. 2006. World development indicators CD-ROM 2006, Washington, D.C.

World Trade Organisation (WTO). 2001. Guide to the GATS: An overview of issues for further liberalisation of trade in services, World Trade Organisation, Kluwer Law International, The Hague

World Trade Organisation (WTO). 2004. World trade report 2004, World Trade Organisation, Geneva

World Trade Organisation (WTO). 2006. World trade report 2006, World Trade Organisation, Geneva 
